\title{
The Importance of Financial Ratios in Predicting Stock Price Trends: A Case Study in Emerging Markets
}

\author{
Thomas Arkan*
}

\begin{abstract}
The purpose of this article is to investigate the importance of financial ratios derived from financial statements to predict stock price trends in emerging markets. A statistical examination to the prediction power of 12 financial ratios was tested depending on data of 15 companies distributed on 3 sectors for the years 2005-2014 in the Kuwaiti financial market. An equation to estimate the stock price in each sector was built according to the multiple regression model after eliminating non-effective variables with the STEPWISE method. The results showed that some ratios could give strong positive and significant relationships to stock price behaviour and trends, the most effective ratios on the stock price for the industrial sector are ROA, ROE and net profit ratio. Also the most effective ratio on the stock price for the service sector was the ROA, ROE, P/E and EPS ratio and the same for the investment sector. This study concluded that it could rely on a set of financial ratios for each sector to predict stock price, the decision maker of such investors can rely on the financial analysis presented by the financial ratios when making financial and operational decisions.
\end{abstract}

Keywords: financial ratios, stock price

\section{Introduction and literature review}

The Primary aim of financial reporting is to provide information about the financial position and performance of companies provided by numbers disclosed in financial statements which was considered to be a guide for their decisions. The Users of accounting information in order to evaluate and forecast the profitability, equity growth, cash flow and dividends of corporates' economic and subsequent decisions, they rely more than any other information on data arising out of financial statements or its components. Numbers in financial reporting could affect investor confidence in financial markets. Investors are looking for opportunities to invest additional resources in the most efficient capital markets and one of the main factors that every investor has in making his/her decision is to give special attention to "stock price".

It is known that financial ratios are the oldest and simplest practical tools in evaluating and planning companies' performance. They appeared in the mid nineteenth century, and

\footnotetext{
*Thomas Arkan, University of Szczecin, Department of Economics, e-mail: danmarkkbh@yahoo.com.
} 
it was always used by accountants and financial analysts. Financial ratios were used by internal and external users for making their economic decisions; including investing, and performance evaluation decisions. Many financial and accounting models have been developed over the past few decades. However, the financial ratios still kept their classical and fundamental power as models or as another important supportive analysis for financial and planning analysis.

The use of accounting data and financial ratios to explain changes in stock prices is frequently referred to in the literature, using a financial ratio analysis can be largely attributed to changes in stock prices has often been discussed by academics and financial analysts.

Kendall (1953) observes that stock prices seem to change randomly over time, and he tested whether a previous price could be used to predict a future price change.

Later, studies expanded to include other predictive variables such as dividend yield, price to earnings ratio, book-to market ratio, return on equity, and various measures of interest rates that commonly tested to predict stock prices and returns. However, the evidence is mixed.

Ball and Brown (1968) originally researched the correlation between accounting information and stock price. After they empirically studied the correlation between annual report earnings data and stock price, they found that if a company had excess earnings and then investors could get an abnormal return. This shows the relationship between accounting earnings and stock price.

Beaver asserted from another perspective that a company's financial reporting and accounting information could influence stock price. Beaver found that investors used the declared accounting information when they traded in stocks.

Bernard and Stober, Dechow (1994) and Sloan (1996) respectively empirically studied the influence of earnings information and operating cash flow information on stock price. They found that the earnings information is better correlative, but not absolute.

Wright, Ken (1996) in their study entitled: "The role and importance of accounting information when making decisions in the stock." The study examined the role and importance of accounting information when making decisions in securities in order to raise awareness of the behaviour of investors.

Torpedo (2001) in his study determined the predictability of the profitability of companies in the Stock Exchange using their financial ratios. In his own research, he concludes that a financial ratio analysis can have a high correlation with profitability and predictability by multiple regression financial ratios, including a profitability test contract. The companies with low and high profitability were divided into two groups and the results of his research indicate a high potential for profitability in the projected financial ratios.

Long Chen (2007) investigated the factors affecting the stock price and amount an investor would pay to buy, and the results suggest that the most impact factor on stock prices is cash flow. 
Syed (2010) studied the relationship between financial ratios and stock prices in the metallic and non-metallic minerals industry. The results indicate that the linear and non-linear relationship between financial ratios and stock prices and the models of type B (without interception) offer a greater ability to explain the stock price. Quadric nonlinear models are better than the other models which cannot explain the stock price. The proportion of activity in the circulation and Profitability ROA, return on capital and the percentage of non-profit special sales can better explain the stock price

\section{The concepts of financial Ratios and Analysis}

The main objective of a financial a report is to provide information on a company's performance to the internal and external users to take decisions. From the perspective of information economics, accounting and financial reporting play a vital role in an efficient capital market.

One of the most common ways of assessing the relative values of stocks among practitioners is to compare the numbers listed in financial statements by using financial ratios. The main advantage of using financial ratios instead of amounts from the income statement is that they are independent of the size of the company. The comparison of financial ratios is used to assess companies' financial condition, operations and attractiveness as an investment. Based on their characteristics academics have already been studying financial ratios widely for almost a century.

Financial ratios defined as the numerical value created from two or more values taken from a company's financial statements i.e. its balance sheet, income statement or statement of cash flow. Typically, financial ratios are presented as a quantified metric in the form of a percentage, multiple or a ratio which aims to evaluate the financial, operational performance and competitiveness of a company.

Matar (2010) defines the financial analysis as "a process by which exploration or derivation group of quantitative and qualitative indicators of economic activity around the project contributes to determine the significance of the properties of the activities of the operations and financial position, in order to use these indicators in assessing the performance of the companies with a view to making decisions".

While Momani believes that financial analysis is a "detailed study of the financial reports in order to identify the strengths and weaknesses of companies in these accounts and diagnose problems in order to find solutions and by studying the historical information to determine past and future Orientalism".

The financial Ratio Analysis has been developed over many years and it has become more than a tool of evaluation. It helps tax department's credit analysis in banks, financial market councils and CPA Accountants to determine some critical points in their jobs. 
The wide use of this ratio is growing because it is easy to calculate financial ratios, and for being a quantitative measure to judge the internal units, also the financial ratios provide basic indicators for judging performance without the need to provide some financial details.

In general, the extent and depth of financial statement analysis is determined by user requirements, On the other hand an analyst about to make a decision whether to invest in a firm is interested in its future performance. The technique involves the calculation of a number of ratio indicators which attempt to express the relationships which exist between key financial variables which appear principally in the published financial statements. The values for individual ratios are then compared with an appropriate standard to ascertain whether they are satisfactory or otherwise. Three main types of comparisons are widely employed:

(1) Cross sectional comparison:

(a) intra-industry - then the subject firm is compared with other firms in the same industry. The industry average for each ratio is the standard employed.

(b) Inter-industry - the subject firm is compared with other firms in different industries, and the results of other firms or the averages of other industries are the standards employed. This approach is fraught with difficulty since the differing risk structures of industries make unadjusted raw results difficult to compare.

(2) Intertemporal comparison - intra-firm - the subject firm's ratios are compared across time for the identification of trends or other relationships.

(3) Arbitrary standards comparison - ratios of the subject firm are rated against "traditional" standards.

I developed a chart to show the recent development of financial ratios analysis and factors effects on it. The qualitative characteristics of accounting information are the cornerstone of starting point in financial analysis. The rest of modern analysis in advanced modern systems depends on pre-formulated model that use this information either internally or externally by investors or other parties.

There is a vast amount of information that can be attained by analysing and breaking down the financial statements. When analysing the financial statements of companies a large number of financial ratios could be used, these ratios can be divided into several groups and each group studies a certain phenomenon depending on the intended purpose of the financial analysis for example, short-term debt holders focusing on the study of specific percentages differ from the ratios that are focused on and studied by owners' Long-term debt, the financial ratios are divided into five categories that all highlight different aspects of a company's financial and operational performance. These categories represent measures of liquidity, profitability, debt, operating and investment valuation. Each category is described in detail shown below: Brigham (2005); Ross (1999). 


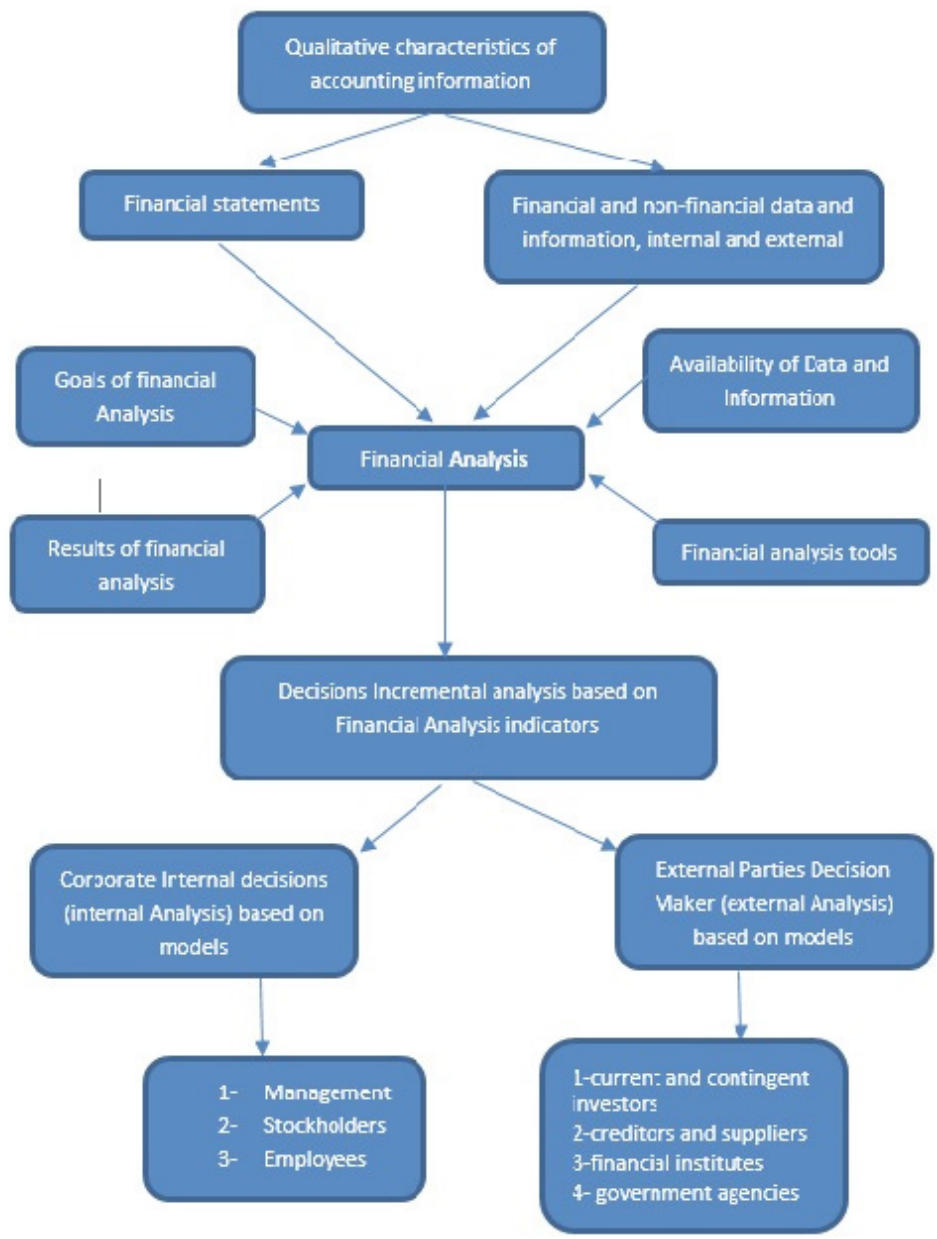

Figure 1. Modern Approach to financial statement analysis

Source: researcher's efforts.

\subsection{Leverage (debit) Financial Ratios}

This group of financial ratios show the percentage of a company's capital structure that is made up on debt or liabilities owed to external parties, also it focuses on a company's ability to meet its long-term debt obligations. Focusing on the long-term solvency in general, the more leveraged and higher amount of debt financing relative to equity financing, the owner faces then greater is the risk. Besides higher leverage is usually associated with higher expected returns. The most common financial leverage ratios are the total debt ratios, the 
debt/equity ratio, the long-term debt ratio, the times interest earned ratio, the fixed charge coverage ratio, and the cash coverage ratio.

\subsection{Liquidity (solvency) Financial Ratios}

The liquidity or solvency ratios group focuses on a firm's ability (current assets and current liabilities) to meet its short-term debt obligations. In other words, it lets you know the resources available for a firm to use in order to pay its current obligation and expenses. If a company cannot maintain a short-term debt-paying ability, it will not be able to maintain a long-term debt-paying ability, nor will it be able to satisfy its stockholders. The main ratio in this group is the current ratio and acid test ratio.

\subsection{Financial Operation Ratios (Asset Efficiency) ratios}

The Financial Operation Ratios group which is sometimes called asset management ratios, measure the efficiency with which a firm manages and controls its assets (utilizing its capital) in generating sales and earnings. Investors can use these in order to analyse a company's or management's ability to efficiently use resources and how effective it converts its purchases and inventory to sales and then its sales to cash.

\subsection{Profitability Financial Ratios}

The profitability ratios group, also known as performance ratios, assesses the company ability to earn profits on sales, assets and equity, it measures the return earned on a company's capital and the financial cushion relative to each dollar of sales, These are critical to determining the attractiveness of investing in company shares, and investors in using these ratios widely, much like the operational performance ratios, these ratios give users a good understanding of how well the company utilized its resources(assets) in generating profit and shareholder value. The long-term profitability of a company is vital for both the survivability of the company as well as the benefit received by shareholders.

\subsection{Valuation ratios (market value ratios)}

The valuation ratios group indicates to the market value of a stock in terms of some measure of a company's fundamentals such as EP, book value, EPS, ROE, and dividends. These ratios are the ones that investors tend to look at on a daily basis and they change whenever the price of the stock changes. These ratios allow you to compare your company to others in your industry. They also allow you to compare different time periods of data for your company to another one.

Table 1 shows each group of previous ratios and its sub-ratio in detail, its uses and formulas. 


\section{Table 1}

Main groups and sub-groups of financial ratios

\begin{tabular}{|c|c|c|}
\hline Discussion & Calculation & Ratio \\
\hline \multicolumn{3}{|l|}{ Grope 1: liquidity (solvency) ratios } \\
\hline $\begin{array}{l}\text { Shows the company's ability to meet } \\
\text { its current obligations (or pay off } \\
\text { debt). }\end{array}$ & Current Assets $\div$ Current Liabilities & Current Ratio \\
\hline $\begin{array}{l}\text { This ratio eliminates inventory and } \\
\text { other current assets from the deno- } \\
\text { minator, focusing on "near cash" and } \\
\text { receivables }\end{array}$ & $\begin{array}{l}\text { Current Assets - Inventory - Prepaid } \\
\text { items } \div \text { Current Liabilities }\end{array}$ & Quick Ratio \\
\hline \multicolumn{3}{|l|}{ Grope 2: leverage (debit) financial ratios } \\
\hline $\begin{array}{l}\text { An indication of the ability of the } \\
\text { company to absorb losses without } \\
\text { risking assets. }\end{array}$ & Debt $\div$ Total Assets & Debt Ratio \\
\hline \multirow{2}{*}{$\begin{array}{l}\text { Direct comparison of debt to equity } \\
\text { stakeholders and the most common } \\
\text { measure of capital structure. }\end{array}$} & $\begin{array}{l}\text { Total Liabilities } \div \text { Total Stockholders' } \\
\text { Equity }\end{array}$ & Debt to Equity \\
\hline & $\begin{array}{l}\text { Short Term Liabilities } \div \text { Total Stoc- } \\
\text { kholders' Equity }\end{array}$ & Short-term Debt to Equity \\
\hline
\end{tabular}

Grope 3: Operation Ratios (assets efficiency)

\begin{tabular}{|c|c|c|}
\hline $\begin{array}{l}\text { Measures the efficiency of net fixed } \\
\text { asset (property, plant \& equipment } \\
\text { after accumulated depreciation) } \\
\text { investments }\end{array}$ & Sales $\div$ Average Fixed Assets & Fixed Asset Turnover ratio \\
\hline $\begin{array}{l}\text { Represents the overall (comprehensi- } \\
\text { ve) efficiency of assets to sales. }\end{array}$ & Sales $\div$ Average Total Assets & Total Asset Turnover ratio \\
\hline \multicolumn{3}{|l|}{ Grope 4: profitability Ratios } \\
\hline $\begin{array}{l}\text { Shows the productivity of the com- } \\
\text { pany in terms of its use of assets to } \\
\text { generate profits }\end{array}$ & Net Income $\div$ Average Total Assets & Return on Total Assets Ratio \\
\hline $\begin{array}{l}\text { Ratio shows how efficiently the com- } \\
\text { pany is using common shareholder's } \\
\text { equity. }\end{array}$ & $\begin{array}{l}\text { Net Income available to Common } \\
\text { Stockholders } \div \text { Average Common } \\
\text { Stockholders' Equity }\end{array}$ & Return on Equity Ratio \\
\hline \multirow{2}{*}{$\begin{array}{l}\text { This captures the relationship between } \\
\text { sales and manufacturing (or merchan- } \\
\text { dising) costs. (Also, called gross profit } \\
\text { margin.) }\end{array}$} & $($ Sales - COGS $) \div$ Sales & Gross Margin Ratio \\
\hline & Net profit After Tax $\div$ Net Sales & Net Profit Ratio \\
\hline \multicolumn{3}{|c|}{ Grope 5: Valuation ratios (Market value ratios) } \\
\hline Measure of accounting-based equity & $\begin{array}{l}\text { (Stock Price x Number of Shares Out- } \\
\text { standing) } \div \text { Total Stockholders' Equity }\end{array}$ & $\begin{array}{l}\text { Earnings per share Ratio (EPS) } \\
\text { Market-to-book }\end{array}$ \\
\hline $\begin{array}{l}\text { Measure of market premium paid for } \\
\text { earnings and future expectations }\end{array}$ & Stock Price / EPS & Price Earnings Ratio (PE) \\
\hline $\begin{array}{l}\text { Equity or net assets, as measured on } \\
\text { the balance sheet }\end{array}$ & $\begin{array}{l}\text { Total Stockholders' Equity } \div \text { Number } \\
\text { of Shares Outstanding }\end{array}$ & Book Value Per Share \\
\hline
\end{tabular}

Source: research collection from various references listed in bibliography. 
The usage of financial ratios has several limitations.

First: the fairness of accounting information to a large extent, an external analyst relies on the fairness of published financial statements by the firm's. Consequently, the information which is obtained from this ratio is constrained by the quantity and accuracy (quality) of the data contained in the published reports. In short, his analysis inherits all the shortcomings and defects contained therein. Some specific problems include:

(1) Inadequate disclosure.

(2) Lack of comparability.

Second: the poorness of prediction: the predicted future financial statements reflect past events of performances. There are a lot of restrictions and boundaries for this estimation, future decisions concern past events and if they would be useful for such a credit analysis but most of the future behaviour of specified variable such stock prices would be affected by another variable either fuzzy variables or non-controllable variables.

Third: the lack of giving answers: ratios are not ends in themselves although this point is most frequently overlooked by the novice analyst. Ratios raise the important question of "why?" For example, if they indicate declining firm profitability the analyst needs to know why is it that profitability declined. Once that is when the answers to this question give a sounder position to determine whether the condition will continue in the future and how it will affect investment decisions. Thus ratios do not give yes/no, black/white or type answers. They are attention directing and not problem solving. Hence it is necessary to look behind the ratios. It is the interpretation of the ratios which is most important.

\section{Stocks and prices}

Stocks are the most common and actively traded securities in financial markets, it is regarded as a long-term source of funding, Stocks (shares) give the holder the right to receive profit in the case of an entity to achieve profits (or bear the loss as much as shares, and the right to own part of a company and entitles this right of management both through its membership in the general assembly of shareholders or by the Board of Directors, therefore the stock price rises whenever the profit distributions happen as cash based or of another type.

Investopedia (2016) define stocks as a type of security that signifies ownership in a corporation and represents a claim on a part of the corporation's assets and earnings. There are two main types of stock: common and preferred. Common stock usually entitles the owner to vote at shareholders' meetings and to receive dividends. Preferred stock generally does not have voting rights, but has a higher claim on assets and earnings than just shares. For example, owners of preferred stock receive dividends before public shareholders and have priority in the event that a company goes bankrupt and is liquidated.

Through the previous definitions it can be seen that there are several characteristics of the stock (shares) including:

- the per share in the capital of the enterprise, 
- the ability to share trading,

- the limited liability afforded to the holder of the stock by its share in the capital or equity,

- equality to the value of the stock for the same facility.

Studying the movement of stock prices and the volatility of prices is considered to be the most important mission in the financial world and markets many researchers since the last century have tried to identify the factors affecting the price of stock, which was behind the change in the price, and trying to study these factors and interpretations in order to take advantage of it to know the impact on stock price, for example investors are very interested in the stock's price because the price is one of factors that affect the sale or purchase decision, there are many factors that can impact on the stock price in financial markets, which varies in terms of power and could have an influence from factor to another and from market to market and by a time series. These factors could be presented as:

1. Book value of stock.

2. Profits realized per share of the basic determinants of the price of the share's profitability.

3. Dividends at the end of each year.

4. Expectations about the future of the facility and the strength of its financial position.

5. General economic conditions of the country.

6. Rumours in financial markets.

7. Supply and demand situation on stock in the financial market.

8. Interest rate.

\section{Research methodology and results}

This study will be achieved in the Kuwaiti Stock Market which is an example of an emerging market because most of the previous studies were conducted in developed countries 15 companies in three sectors selected from the listed company in the Financial market for the years between 2005-2014. Statistical analysis was used to test the main and Sub hypothesis which concentrated on finding the relationship and predictability power of each ratio in estimating stock price trends, by using the SPSS Software at 0.05 confidence level. Also a goal was to find an equation that could explain the relationship between dependent variables (financial ratios) and independent variable (stock price), a multiple regression analysis used to achieve this mission, a stepwise method in the analysis was used to reveal only the variables which significantly affect the dependent variable.

The Main hypothesis of this article is to find out whether there is a statistically significant correlation between the financial analysis ratios as dependent variables (in 5 main groups of ratios) and trends of stock prices. A sub-hypothesis builds on inverse assumption for each ratio in the sector. 
Table 2 shows the results of a Statistical test of the study sample which is divided into 3 sectors: industrial, services and financial.

Table 2

Statistical analysis for dependent and independent variables for the sample test

\begin{tabular}{lllllllllllll}
\hline \multicolumn{1}{l}{ Correlation analysis between dependent and independent variables in the model for different Sectors } \\
\hline Sectors & \multicolumn{1}{c}{ Industrial Com } & \multicolumn{7}{c}{ Services Com } & \multicolumn{5}{c}{ Investment Com } \\
Ratios/statistics & $\mathrm{r}$ & $\mathrm{r}^{2}$ & $\mathrm{Sig}$ & $\mathrm{r}$ & $\mathrm{r}^{2}$ & $\mathrm{Sig}$ & $\mathrm{r}$ & $\mathrm{r}^{2}$ & $\mathrm{Sig}$ \\
Current Ratio & -0.5 & 25.08 & 0.013 & -0.323 & 10.41 & 0.083 & 0.779 & 60.6 & 0.00 \\
ROA & 0.679 & 46.19 & 0.00 & 0.404 & 16.24 & 0.0391 & 0.483 & 23.29 & 0.017 \\
ROE & 0.809 & 65.21 & 0.00 & 0.394 & 15.43 & 0.044 & 0.465 & 21.74 & 0.0191 \\
Net Profit \% & 0.74 & 54.67 & 0.00 & ---- & --- & --- & ---- & --- & --- \\
Short T Debt/Equity & 0.738 & 54.26 & 0.00 & 0.274 & 7.51 & 0.122 & -0.407 & 16.51 & 0.039 \\
Assets Turn over & 0.248 & 6.1 & 0.148 & -0.376 & 14.11 & 0.056 & ---- & ---- & ---- \\
Current Assets Turn over & 0.252 & 6.32 & 0.144 & -0.009 & 0.011 & 0.488 & ---- & ---- & ---- \\
Fixed Assets Turn over & 0.836 & 69.67 & 0.00 & -0.0456 & 20.72 & 0.023 & ---- & ---- & ---- \\
EPS & 0.188 & 3.5 & 0.216 & 0.531 & 28.19 & 0.009 & 0.469 & 21.92 & 0.0191 \\
Share Market V/ Book V & 0.91 & 82.6 & 0.00 & 0.859 & 73.54 & 0.00 & 0.984 & 96.68 & 0.000 \\
P/E & -0.349 & 12.11 & 0.067 & 0.421 & 17.65 & 0.034 & 0.151 & 2.241 & 0.272 \\
Book V per Share & 0.819 & 66.97 & 0.00 & 0.526 & 27.65 & 0.0091 & 0.476 & 22.61 & 0.018 \\
Total debits/equity & ---- & ---- & ---- & ---- & ---- & --- & -0.338 & 11.4 & 0.074 \\
Contribution Margin \% & ----- & ---- & ---- & 0.415 & 17.13 & 0.035 & ---- & ---- & ---- \\
\hline
\end{tabular}

Correlation statistically significant at 0.05 .

Source: research findings.

From the Table 2 the statistical analysis results can be seen below:

1. Industrial sector companies

There is no significant statistical positive relation between current ratio and stock price where Sig $(0.013)$ is less than the confidence degree at $(0.05)$. The correlation is negative at (0.5), the R2 (25.08) which means the independent variable (current ratio) was able to explain only $25.08 \%$ from the behaviour of the dependent variable and $(74.92 \%)$ of the stock trend affected by other variables.

There is a significant positive relationship between ROA and stock price at R (0.679) and Sig (0.00), where R2 (46.19\%) which explains also a wide range of stock trends.

Also there is a positive significant relationship between ROE and stock price where this variable was able to explain (65.21\%) of stock price behaviour in the market.

Also there are significant positive relationships between each of the net profit ratios, current debt to equity ratio, fixed assets turnover ratio, market to book value ratio and book value ratio with stock price trend approved by a degree of the calculated Sig compared with the degree of confidence (I depend on it in the analysis). 
The other ratios did not show a significant relationship between ratio and stock price such total assets as turnover, current assets turnover ratio, EPS and P/E ratio. The correlation of these factors with stock price was weak and its ability to explain stock trends was poor also.

By using SPSS software with Stepwise method shows only independent significant variables (ratios) that have an effect on stock price behaviour in the multiple regression model to get an equation presents the relationship between dependent and independent variables the results reveal that only market to book value ratio and book value ratio have a strong correlation with stock price at $\mathrm{R}(0.99)$ and $\mathrm{R}^{2}(99.2 \%)$ with the variance analysis of regression of the F (1040.1) and Sig (0.00) which refer to a positive significant relation between these dependent variables and stock price. The T-test shows values of $\{(-18.402),(26.2)$ and 18.8) $\}$ for constant, $\mathrm{X}_{1}$ and $\mathrm{X}_{2}$ respectively. The estimated equation to predict stock price for this sector are:

$$
\text { Estimated stock price }=-1.86+1.7 \mathrm{x}_{1}+1.18 \mathrm{x}_{2},
$$

where:

$\mathrm{x}_{1}-$ market to book value ratio,

$\mathrm{x}_{2}-$ book value ratio.

\section{Service sector companies}

The analysis of the results in the service sector shows that each of the current ratio, short term liabilities ratio, total assets turnover, fixed assets turnover and current assets turn- over do not have a significant relationship with stock price behaviour. The Sig Value did not pass the confidence degree according to the main hypothesis. The ability of this independent variable to explain the trends of the dependent variable was too poor.

The dependent variable of ROA, ROE, net profit ratio, EPS, market to book value/E ratio and book value ratio have a positive significant relationship with stock price trends.

The multiple regression equation that could estimate the trend of stock price in this sector could be presented below where the mostly effected variable in stock price by applying the STEPWISE method was the market to book value ratio, PE ratio, short term liabilities ratio and net profit ratio, with a multiple correlation at (0.995) and $\mathrm{R}^{2}(98.4)$. the F-test shows (251.8) At Sig (0.00) which refer to a high significant relationship with the independent variable, the T-value of independent variables was $\{(0.004),(24.3),(-6.5),(-4.8,3.3)$ and $(3.3)\}$ respectively, the estimated equation to predict stock price for this sector are:

$$
\text { Estimated stock price }=0.002+1.9 \mathrm{x}_{1}-0.02 \mathrm{x}_{2}-0.95 \mathrm{x}_{3}+2.05 \mathrm{x}_{4},
$$

where:

$\mathrm{x}_{1}$ - market to book value ratio,

$\mathrm{x}_{2}-\mathrm{PE}$ ratio,

$\mathrm{x}_{3}$ - short term liabilities to equity ratio,

$\mathrm{x}_{4}-$ Net profit ratio. 
3. Investment sector companies

The results show significant positive variables (current ratio, ROA, ROE, EPS, market to book value ratio and book value ratio) with stock price, each variable with the Sig value less than a degree of confidence approve acceptance of the null hypothesis. This variable shows a positive correlation with stock price and the degree of explaining of the behaviour of stock in the market was a high.

Each of the short term liabilities to equity ratio, debit to equity ratio and EPS ratio did not show any significant relationship with stock price trend as a dependent variable. The value of Sig was greater than the degree of confidence dependent in this test. The correlation between these ratios and stock price was either too poor or negative.

The aggregation of the affected variables to create an estimate equation for stock price trend shows that only the market to book value ratio, EP ratio; ROE and EPS have a significant relationship with the multiple regression analysis. The $\mathrm{R}$ value was $(0.997)$ and $\mathrm{R}^{2}$ $(99.89 \%)$. With the analysis of variances of regression, the F-test value was (3150.8) And Sig $(0.00)$. The T-test for each variable was $\{(-4.156),(98.5),(8.1),(-6.1)\}$ respectively. The estimated equation for predicting stock could be presented as follows:

$$
\text { Estimated stock price }=-1.42+1.15 \mathrm{x}_{1}+8.3 \mathrm{x}_{2}+9.3 \mathrm{x}_{3}-1.2 \mathrm{x}_{4} \text {, }
$$

where:

$$
\begin{aligned}
& \mathrm{x}_{1}-\text { market to book value ratio, } \\
& \mathrm{x}_{2}-\text { PE ratio, } \\
& \mathrm{x}_{3}-\text { ROE ratio, } \\
& \mathrm{x}_{4}-\text { book value ratio. }
\end{aligned}
$$

\section{Conclusions}

From the practical side and hypothesis test I can conclude some important points that can be seen below:

1. The new approach of the financial analysis had passed the old criticism to the function of it. The approach focusing on the integrity between accounting as an information system (qualitative characteristics of accounting information), tools of analysis, internal and external environment. The modern approach relay on the integrity between accounting, maths, and statistics to get the desired goals.

2. Top management, financial analysts and investors can rely on a specified set of financial ratios in their evaluation for each financial and operational performance of companies and when making decisions.

3. To perform a financial analysis process in an accurate and prices way which is desired by investors and analysts, it requires the presence of multiple criteria to measure performance and compare the results by others in the same sector. 
4. The results of the financial ratio analysis with statistical methods shows that the profitability ratios group and valuation ratios group have a significant effect on stock prices. The combination of the financial ratios enhances stock price predictability.

5. In the industry sector for Kuwaiti companies in the financial market, the power ability of financial ratios to predict the stock price trend was tested using a statistical analysis with a multiple linear regression for the years between (2005-2014), 12 financial ratios were tested, the test results showed that there were (2) variables (market to book value and book value ratio) have a statistically significant stock price and thus can identify the model to predict the price of the share of the industrial sector.

6. In the services sector also a 12 financial ratio was tested for the years between (20152014), only 4 ratios passed the test that would affect the prediction of the stock price. A market to book value ratio, PE ratio, short term liabilities to equity ratio and net profit ratio have the most power influence in the prediction equation.

7. In the investment sector the market to book value ratio, EPS ratio, ROE ratio and book value ratio were found a most effective variable in predicting the future value of the stock price prediction equation.

8. This study was compatible with some universal studies in its analysis and the results found out that there is a common ratio between our study and others that would have an affect stock price prediction and influences such a market to the book value ratio, book value ratio, ROE, PE, EPS and Net Income Ratio.

\section{References}

Altman E.I. (1968), Financial Ratios, Discriminant Analysis and the Prediction of Corporate Bankruptcy, "The Journal of Finance" vol. 23, no. 4.

Basu S., Investment performance of common stocks in relation to their price-earnings ratios: a test of the efficient market hypothesis, "Journal of Finance" vol. 32, no. 3.

Beaver, W.H., Beaver W.H. (1966), Financial Ratios as Predictors of Failure, "Journal of Accounting Research" vol. 4 , no. 3 .

Benninga Simon, (2008), Financial Modeling, 3rd, Massachusetts Institute of Technology.

Block S.B. (1999), A study of financial analysis: practice and theory, "Financial Analysts Journal” vol. 55, no. 4.

Brigham E.F., Ehrhardt M.C. (2005), Financial Management, 11 edition, USA.

Campbell J.Y., Campbell J.Y., Shiller R.J. 1998, Valuation Ratios and the Long-Run Stock Market Outlook, "Journal of Portfolio Management" vol. 24, no. 2.

Campbell J.Y., Shiller R.J. (1988), Stock Prices, Earnings and Expected Dividends, “Journal of Finance” vol. 43, no. 3.

Chen P.F., Zhang G. (2007), How Do Accounting Variables Explain Stock Price Movements? Theory and Evidence, "Journal of Accounting and Economics", HKUST Business School Research Paper no. 07-02.

Chen S.W., Shen C.H. (2009), Is the Stock Price Higher than that Implied by the Fundamentals?, "International Research Journal of Finance and Economics" vol. 29.

Constand R.L., Freitas L.P., Sullivan M.J. (1991), Factors affecting price earnings ratios and market values of Japanese firms, "Journal Financial Management" vol. 20, p. 4.

Deaves R., Miu P., White C.B. (2008), Canadian stock market multiples and them predictive content, "International Review of Economics and Finance", vol. 17, no. 3.

Hoover S., Ebrary I. (2006), Stock valuation: an essential guide to Wall Street's most popular valuation models, New York: McGraw-Hill, cop. 
Johnson W.B., Zhao R. (2012), Contrarian Share Price Reactions to Earnings. Surprises, "Journal of Accounting, Auditing \& Finance" vol. 27, no. 2.

Koller T, Goedhart M, Wessels D. (2010), Valuation: Measuring and Managing the Value of Companies, 5th ed, John Wiley \& Sons, Hoboken.

Kothari S.P., Shanken J. (1997), Book-to-market, dividend yield, and expected market returns: a time series analysis, "Journal of Financial Economics" vol. 44.

Lewellen J. (2004), Predicting Returns with Financial Ratios, "Journal of Financial Economics” vol. 74.

Li-Chin J., Chao-Shin L. (1997), Open-Market Stock repurchase announcements and revaluation of prior accounting information, "The Accounting Review vol. 25, no. 99.

M.-C. Lin A., Lee R.-T., Kao, Chen K.-T. (2011), Stock price movement prediction using representative prototypes of financial reports, ACM Transactions on Management Information Systems (TMIS), vol. 2, no. 3, pp. Article 19, 18 pages, October.

McWilliams J. (1996), Price, earning and P-E ratios, "Financial Analysts Journal" vol. 22.

Murphy J.J. (1999), Technical Analysis of the Financial Markets: A Comprehensive Guide to Trading Methods and Applications (New York Institute of Finance).

Ohlson J.A., Ohlson J.A. (1980), Financial Ratios and the Probabilistic Prediction of Bankruptcy, "Journal of Accounting Research" vol. 18, no. 1.

Penman S.H, (2010), Financial Statement Analysis and Security Valuation, 4th ed, McGraw- Hill, New York.

Penman S.H., Penman S.H. (1996), The Articulation of Price-Earnings Ratios and Market-to-Book Ratios and the Evaluation of Growth, "Journal of Accounting Research" vol. 34, no. 2.

Penman S.H., Richardson S.A., Tun I. (2007), The book-to-price effect in stock returns: Accounting for leverage, "Journal of Accounting Research" vol. 45, no. 2.

Pontiff J., Schall L. (1998), Book-to-market ratios as predictors of market returns, "Journal of Financial Economics" vol. 49.

Ross S.A., Westerfield R.W., Jaffe J., Ku S. (1999), Corporate Finance, McGraw-Hill College.

Schrimpf A., (2010), International stock return predictability under model uncertainty, "Journal of International Money and Finance" vol. 29.

\section{ZNACZENIE WSKAŹNIKÓW FINANSOWYCH W PRZEWIDYWANIU TENDENCJI CEN AKCJI: STUDIUM PRZYPADKU DLA RYNKÓW WSCHODZĄCYCH}

Streszczenie: Celem niniejszego artykułu jest zbadanie znaczenia wskaźników finansowych obliczanych na podstawie sprawozdań finansowych w przewidywaniu tendencji cen akcji na rynkach wschodzących. Przeprowadzono badanie statystyczne mocy predykcyjnej 12 wskaźników finansowych na podstawie danych z 15 spółek rynku finansowego w Kuwejcie reprezentujących 3 sektory w okresie 2005-2014. W celu oszacowania ceny akcji w danym sektorze, dla każdego z nich skonstruowano odrębne równanie z wykorzystaniem modelu regresji wielorakiej, eliminując zmienne nieefektywne za pomocą metody STEPWISE. Wyniki pokazały, że niektóre wskaźniki wykazują silnie dodatnie i istotne związki z zachowaniem się cen akcji i tendencjami w zakresie ich kształtowania się, przy czym najbardziej efektywne w sektorze przemysłowym okazały się wskaźniki: ROA, ROE oraz zysk netto. Podobnie rzecz przedstawiała się w pozostałych dwóch sektorach, usług i inwestycyjnym, gdzie najbardziej efektywne były wskaźniki: ROA, ROE, P/E oraz EPS. W badaniu stwierdzono, że - przewidując ceny akcji - w każdym sektorze można opierać się na zestawie wskaźników finansowych; inwestor może polegać na analizie finansowej przedstawionej za pomocą wskaźników finansowych przy podejmowaniu decyzji finansowych i operacyjnych.

Słowa kluczowe: wskaźniki finansowe, cena akcji

\section{Citation}

Arkan T. (2016). The Importance of Financial Ratios in Predicting Stock Price Trends: A Case Study in Emerging Markets. Finanse, Rynki Finansowe, Ubezpieczenia, 1 (79), 13-26; www.wneiz.pl/frfu. 